\title{
Identification and fine mapping of qGR6.2, a novel locus controlling rice seed germination under salt stress
}

Peng Zeng ${ }^{1}$, Peiwen Zhu ${ }^{1}$, Luofeng Qian ${ }^{1}$, Xumei Qian ${ }^{1}$, Yuxin $\mathrm{Mi}^{1}$, Zefeng Lin ${ }^{1}$, Shinan Dong ${ }^{1}$, Henrik Aronsson ${ }^{2}$, Hongsheng Zhang ${ }^{1 *}$ and Jinping Cheng ${ }^{1 *}$ (D)

\begin{abstract}
Background: Rice growth is frequently affected by salinity. When exposed to high salinity, rice seed germination and seedling establishment are significantly inhibited. With the promotion of direct-seeding in Asia, improving rice seed germination under salt stress is crucial for breeding.

Results: In this study, an indica landrace Wujiaozhan (WJZ) was identified with high germinability under salt stress. $A B_{1} F_{2}$ population derived from the crossing WJZ/Nip (japonica, Nipponbare)//Nip, was used to quantitative trait loci (QTL) mapping for the seed germination rate (GR) and germination index (Gl) under $\mathrm{H}_{2} \mathrm{O}$ and $300 \mathrm{mM} \mathrm{NaCl}$ conditions. A total of 13 QTLs were identified, i.e. ten QTLs under $\mathrm{H}_{2} \mathrm{O}$ conditions and nine QTLs under salt conditions. Six QTLs, qGR6.1, qGR8.1, qGR8.2, qGR10.1, qGR10.2 and qG/10.1 were simultaneously identified under two conditions. Under salt conditions, three QTLs, qGR6.2, qGR10.1 and qGR10.2 for GR were identified at different time points during seed germination, which shared the same chromosomal region with qG/6.2, qG/10.1 and qG/10.2 for GI respectively. The $q G R 6.2$ accounted for more than $20 \%$ of phenotypic variation under salt stress, as the major effective QTL. Furthermore, qGR6.2 was verified via the $\mathrm{BC}_{2} \mathrm{~F}_{2}$ population and narrowed to a 65.9-kb region with eleven candidate genes predicted. Based on the microarray database, five candidate genes were found with high transcript abundances at the seed germination stage, of which LOC_Os06g10650 and LOC_Os06g10710 were differentially expressed after seed imbibition. RT-qPCR results showed the expression of LOC_Os06g10650 was significantly up-regulated in two parents with higher levels in WJZ than Nip during seed germination under salt conditions. Taken together, it suggests that LOC_Os06g10650, encoding tyrosine phosphatase family protein, might be the causal candidate gene for $9 G R 6.2$.
\end{abstract}

Conclusions: In this study, we identified 13 QTLs from a landrace WJZ that confer seed germination traits under $\mathrm{H}_{2} \mathrm{O}$ and salt conditions. A major salt-tolerance-specific QTL qGR6.2 was fine mapped to a 65.9-kb region. Our results provide information on the genetic basis of improving rice seed germination under salt stress by markerassisted selection (MAS).

Keywords: Rice, Seed germination, Salt stress, Quantitative trait loci (QTLs), Fine mapping, Marker-assisted selection (MAS)

\footnotetext{
* Correspondence: hszhang@njau.edu.cn; cjp@njau.edu.cn

'State Key Laboratory of Crop Genetics and Germplasm Enhancement, Jiangsu Collaborative Innovation Center for Modern Crop Production, Cyrus

Tang Innovation Center for Crop Seed Industry, Nanjing Agricultural University, Nanjing, China

Full list of author information is available at the end of the article
}

(c) The Author(s). 2021 Open Access This article is licensed under a Creative Commons Attribution 4.0 International License, which permits use, sharing, adaptation, distribution and reproduction in any medium or format, as long as you give appropriate credit to the original author(s) and the source, provide a link to the Creative Commons licence, and indicate if changes were made. The images or other third party material in this article are included in the article's Creative Commons licence, unless indicated otherwise in a credit line to the material. If material is not included in the article's Creative Commons licence and your intended use is not permitted by statutory regulation or exceeds the permitted use, you will need to obtain permission directly from the copyright holder. To view a copy of this licence, visit http://creativecommons.org/licenses/by/4.0/ The Creative Commons Public Domain Dedication waiver (http://creativecommons.org/publicdomain/zero/1.0/) applies to the data made available in this article, unless otherwise stated in a credit line to the data. 


\section{Background}

Soil salinity is the primary abiotic stress affecting crop growth and productivity worldwide [1]. It is estimated that $6 \%$ of the Earth's landmass and 20\% of irrigated land are affected by salinity [2]. Rice is the most important staple food, feeding more than half of the world's population. Compared to wheat, rice is more sensitive to salt stress, and approximately $30 \%$ of the rice-growing area in the world is affected by salinity [3]. According to previous reports, high salinity inhibits seed germination and seedling establishment, reduces plant growth and diminishes rice yield $[4,5]$. Although saline soil could be improved by large-scale irrigation, drainage schemes, and chemical treatment, all these solutions are overly costly [6]. Hence, genetic improvement of salt tolerance has been an important and feasible objective for rice breeding in coastal areas [7].

Salt tolerance is a polygenic trait and highly influenced by the environment [8-10]. To date, hundreds of saltresponse QTLs have been reported at different developmental growth stages in rice [11]. Lin et al. [12] detected two major QTLs ( $q S K C-1$ and $q S N C-7$ ) for $\mathrm{Na}^{+} / \mathrm{K}^{+}$content in the seedling shoot on chromosomes 1 and 7 . Based on the results of QTL mapping, the major QTL $q S K C-1$ has been cloned, which encodes an HKT-type transporter protein regulating $\mathrm{K}^{+}$content in the shoot [13]. Another major QTL, Saltol, was identified and used to breed new salt-tolerant varieties by MAS, such as Pusa44, CR1009, and PR114, which enhances salt tolerance at the seedling stage $[14,15]$.

Salt tolerance at the seed germination stage is not consistently related to other stages, such as the seedling and reproductive stages $[9,16]$. Seed germination is a key parameter of prime significance, and fundamental to total biomass and yield in a plant's life cycle, starting with the uptake of water followed by the protrusion of the radicle through the seed envelopes [17]. During seed germination, salinity results in many disorders and metabolic changes such as changed the enzymes activity causing high solute leakage [18], decreased $\mathrm{K}^{+}$efflux and impeding $\alpha$-amylase activity [19]. Few studies have aimed at genetically dissecting seed germination under salt stress in rice. Wang et al. [4] detected 16 QTLs of rice seed germination ability at $100 \mathrm{mM} \mathrm{NaCl}$ from the japonica variety Jiucaiqing. Approximately 50 loci have been identified for seed germination under salt stress by genome-wide association studies (GWAS) [20-22]. Fujino et al. [23] reported that $q L T G 3-1$ was associated with germination under low temperature through tissue vacuolation and weakening, and also with good seed germinability under high salinity. Recently, a QTL qSE3 promoting seed germination and seedling establishment was identified from a japonica landrace Jiucaiqing at $300 \mathrm{mM} \mathrm{NaCl}$, which encodes a potassium transport
OsHAK21 and mediates seed germination under salt stress through abscisic acid (ABA) metabolism [24]. With the increasing promotion of rice direct-seeding methods, it is of considerable importance to explore more loci or genes for seed germination under salt stress and develop cultivars with a high capacity for seed germination under salt stress by MAS in coastal areas.

In this study, an indica landrace WJZ from Yunan province in China [21] was identified with a high capacity for seed germination under high salt stress. To identify QTL for seed germination, the germination rate (GR) and germination index (GI) of the $\mathrm{BC}_{1} \mathrm{~F}_{2}$ population derived from a cross between WJZ and Nip were evaluated under $\mathrm{H}_{2} \mathrm{O}$ and $300 \mathrm{mM} \mathrm{NaCl}$ conditions. A major QTL qGR6.2 on the short arm of chromosome 6 was specifically identified under $300 \mathrm{mM} \mathrm{NaCl}$ conditions. Additionally, $q$ GR6.2 was verified among the $\mathrm{BC}_{2} \mathrm{~F}_{2}$ population and fine mapped within a 65.9-kb region between Z654 and Z619 markers. This work could be valuable in elucidating the genetic and molecular basis of seed germination under salt stress.

\section{Results}

Characteristics of seed germination for two parents under salt stress

The germination rate (GR), seedling percentage (SP) and germination index (GI) for indica WJZ and japonica Nip seeds were evaluated after 10 days (d) of imbibition under $\mathrm{H}_{2} \mathrm{O}$ and various salt concentration conditions $(150,200,250,300$ and $350 \mathrm{mM} \mathrm{NaCl})$. Both WJZ and Nip germinated readily, with approximately $100 \%$ of the GR and SP for WJZ and Nip under $\mathrm{H}_{2} \mathrm{O}$ conditions (Table 1). However, WJZ had a significantly higher GI (13.93) than Nip (10.51), indicating that WJZ germinated faster than Nip under $\mathrm{H}_{2} \mathrm{O}$ conditions. Under various $\mathrm{NaCl}$ concentrations, there was a significant decrease in GR, SP, or GI of both WJZ and Nip (Table 1), indicating that rice seed germination was inhibited and delayed by salt stress. When exposed to $350 \mathrm{mM} \mathrm{NaCl}$, WJZ seeds displayed $80.03 \%$ of GR, in contrast to $12.22 \%$ of GR for Nip (Table 1), suggesting that WJZ was considerably more salt-tolerant than Nip during seed germination. Considering the greatest variation in GR, SP and GI between the two rice parents, seed germination under salt stress was assessed with $300 \mathrm{mM} \mathrm{NaCl}$ in later experiments.

To better understand the characteristics of the high seed germination ability and salt tolerance of WJZ, the differences in GR and SP between the two parents were further analyzed under $\mathrm{H}_{2} \mathrm{O}$ and $300 \mathrm{mM} \mathrm{NaCl}$ conditions. Under $\mathrm{H}_{2} \mathrm{O}$ conditions, although all seeds of both parents germinated and established seedlings after $120 \mathrm{~h}$ (5 d) of imbibition (Fig. 1a, b), WJZ germinated faster 
Table 1 Phenotypic values of seed germination for the two parents under different $\mathrm{NaCl}$ concentration conditions

\begin{tabular}{|c|c|c|c|c|c|c|}
\hline \multirow{2}{*}{$\begin{array}{l}\mathrm{NaCl} \text { concentration } \\
(\mathrm{mM})\end{array}$} & \multicolumn{2}{|l|}{ GR (\%) } & \multicolumn{2}{|l|}{ SP (\%) } & \multicolumn{2}{|l|}{ GI } \\
\hline & WJZ & Nip & WJZ & Nip & WJZ & Nip \\
\hline 0 & $100.00 \pm 0.00$ & $99.33 \pm 0.82$ & $100.00 \pm 0.00$ & $99.33 \pm 0.82$ & $13.93 \pm 0.43^{b}$ & $10.51 \pm 0.44$ \\
\hline 150 & $99.33 \pm 0.82^{b}$ & $87.77 \pm 2.74$ & $99.33 \pm 0.82^{\mathrm{a}}$ & $85.57 \pm 3.60$ & $12.00 \pm 0.19^{b}$ & $6.62 \pm 0.30$ \\
\hline 200 & $98.67 \pm 0.82^{a}$ & $86.63 \pm 4.08$ & $96.67 \pm 2.37^{b}$ & $68.90 \pm 1.35$ & $10.47 \pm 0.11^{b}$ & $4.96 \pm 0.13$ \\
\hline 250 & $95.53 \pm 2.74^{\mathrm{a}}$ & $77.77 \pm 4.90$ & $88.90 \pm 7.20^{b}$ & $51.13 \pm 3.60$ & $8.24 \pm 0.79^{b}$ & $3.97 \pm 0.11$ \\
\hline 300 & $95.53 \pm 2.74^{b}$ & $34.43 \pm 3.60$ & $65.53 \pm 7.58^{b}$ & $1.11 \pm 0.82$ & $6.92 \pm 0.25^{b}$ & $1.79 \pm 0.10$ \\
\hline 350 & $80.03 \pm 10.80^{b}$ & $12.22 \pm 3.61$ & $26.67 \pm 8.17^{\mathrm{a}}$ & $0.00 \pm 0.00$ & $5.09 \pm 0.71^{b}$ & $0.76 \pm 0.15$ \\
\hline
\end{tabular}

GR germination rate, $S P$ seedling percentage, GI germination index, WJZ Wujiaozhan, Nip Nipponbare

${ }^{a}$ and ${ }^{b}$ indicate significant differences compared to WJZ at the 5 and $1 \%$ levels, respectively

and had higher values of GR and SP than Nip at the beginning of seed germination. Under $300 \mathrm{mM} \mathrm{NaCl}$ conditions, significant differences in GR and SP between WJZ and Nip were observed from 3 to $14 \mathrm{~d}$ during seed germination (Fig. 1c-e). The WJZ began to germinate after
$2 \mathrm{~d}$ of imbibition, and its GR reached $90 \%$ after $7 \mathrm{~d}$ of imbibition (Fig. 1c), with a strong seedling establishment capacity being observed (Fig. 1d, e). However, Nip started to germinate after $7 \mathrm{~d}$ of imbibition and showed only $58.89 \%$ GR after 14 d of imbibition (Fig. 1c).

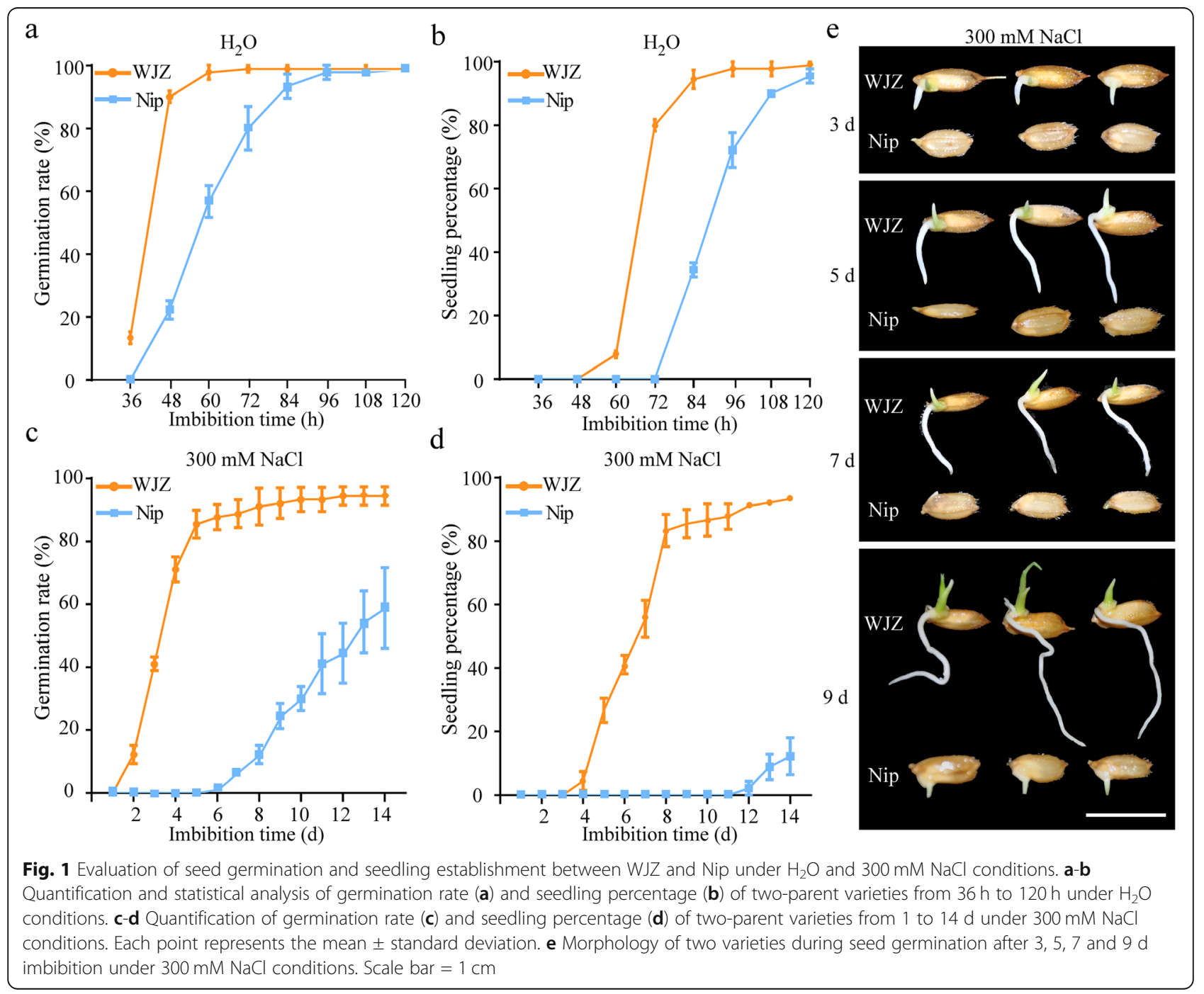




\section{Variation in seed germination traits among the $\mathrm{BC}_{1} \mathrm{~F}_{2}$ populations}

A $\mathrm{BC}_{1} \mathrm{~F}_{2}$ population consisting of 181 individuals was derived from the crossing WJZ/Nip (japonica, Nipponbare)//Nip (Fig. S1a). The variations in GR and GI among this $\mathrm{BC}_{1} \mathrm{~F}_{2}$ population under $\mathrm{H}_{2} \mathrm{O}$ and $300 \mathrm{mM}$ $\mathrm{NaCl}$ conditions were analyzed. All the traits observed, including GR at $2 \mathrm{~d}, 3 \mathrm{~d}$ and GI under $\mathrm{H}_{2} \mathrm{O}$ conditions, GR at $5 \mathrm{~d}, 7 \mathrm{~d}, 9 \mathrm{~d}, 11 \mathrm{~d}, 13 \mathrm{~d}$ and GI under $300 \mathrm{mM}$ $\mathrm{NaCl}$ conditions, showed a continuous distribution and had a wide range of genetic variations (Fig. 2). Under $\mathrm{H}_{2} \mathrm{O}$ conditions, there was a left-skewed distribution of GR at $2 \mathrm{~d}$, a right-skewed distribution at $3 \mathrm{~d}$ (Fig. 2a, b), and a symmetrical distribution of GI (Fig. 2c). Under $300 \mathrm{mM} \mathrm{NaCl}$ conditions, GR showed a left-skewed distribution at $5 \mathrm{~d}$, a right-skewed distribution at 9, 11 and $13 \mathrm{~d}$ during seed germination (Fig. 2d, f-h), and a symmetrical distribution at $7 \mathrm{~d}$ (Fig. 2e). The GI under $300 \mathrm{mM} \mathrm{NaCl}$ conditions showed a right-skewed distribution (Fig. 2i). These results indicated that the traits of GR and GI are polygenic characteristics and might be regulated by various genes at the early and later stages of germination under $\mathrm{H}_{2} \mathrm{O}$ or $\mathrm{NaCl}$ conditions.

\section{QTL mapping of seed germination traits under $\mathrm{H}_{2} \mathrm{O}$ and salt conditions}

A molecular linkage map was constructed with the above $\mathrm{BC}_{1} \mathrm{~F}_{2}$ population for QTL mapping of seed germination traits (GR and GI) under $\mathrm{H}_{2} \mathrm{O}$ and $300 \mathrm{mM}$ $\mathrm{NaCl}$ conditions. Under $\mathrm{H}_{2} \mathrm{O}$ conditions, eight QTLs for GR were identified on chromosomes 3, 6, 8 and 10, and two QTLs for GI were identified on chromosomes 6 and 10 (Table 2). GR at $2 \mathrm{~d}$ was associated with three QTLs ( $q$ GR8.1, qGR8.2 and $q$ GR10.1), and GR at $3 \mathrm{~d}$ was associated with six QTLs (qGR3.1, qGR3.2, qGR3.3, qGR6.1, $q G R 10.1$ and $q$ GR10.2). The phenotypic variation explained (PVE) of GR by a single QTL ranged from 7.32 to $23.99 \%$. One major QTL, $q$ GR6.1 for GR accounted for $23.99 \%$ of phenotypic variation. The $q$ GI6.1 and $q$ GII0.1 for the GI accounted for 10.39 and $8.86 \%$ of phenotypic variation, respectively. By comparison, qGR6.1 and qGI6.1 shared the same interval of RM190 Z602 on chromosome 6, and $q$ GR10.1 and $q$ GI0.1 shared the same interval of W13 W20 on chromosome 10 (Table 2). The additive effects of all these QTLs detected under $\mathrm{H}_{2} \mathrm{O}$ conditions were negative, ranging from -0.36 to -9.95 (Table 2), suggesting that the positive alleles were derived from WJZ.

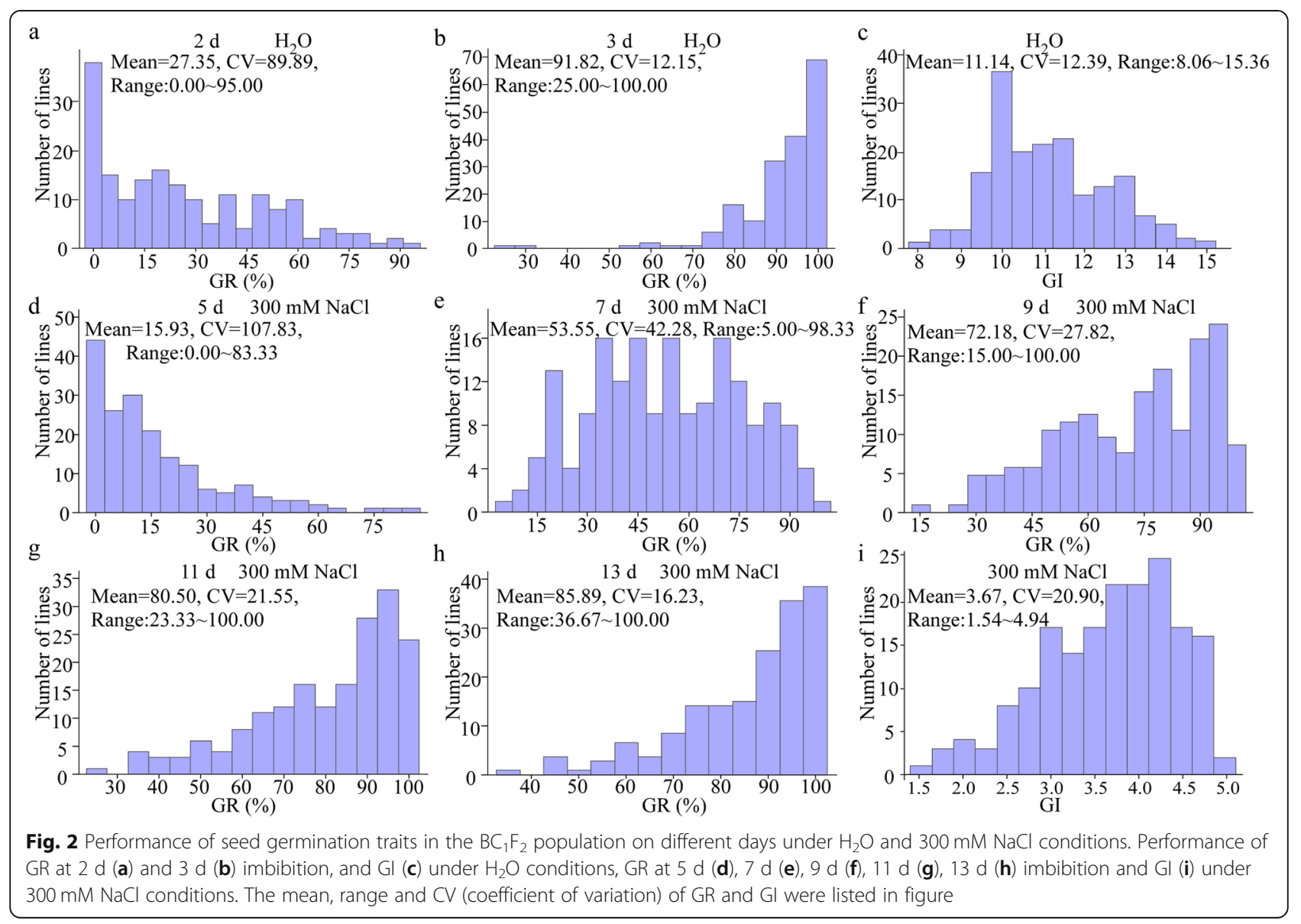


Table 2 QTLs analysis of seed germination traits among $\mathrm{BC}_{1} \mathrm{~F}_{2}$ population under $\mathrm{H}_{2} \mathrm{O}$ and $300 \mathrm{mM} \mathrm{NaCl}$ conditions

\begin{tabular}{|c|c|c|c|c|c|c|c|c|c|c|}
\hline Treatments & Traits & QTLs & $\begin{array}{l}\text { Days after } \\
\text { imbibition }\end{array}$ & Chr. & Left Marker & Right Marker & LOD & PVE (\%) & Add & Dom \\
\hline \multirow[t]{11}{*}{$\mathrm{H}_{2} \mathrm{O}$ (control) } & $G R$ & qGR3.1 & 3 & 3 & Y25 & W33 & 3.22 & 7.32 & -4.92 & 5.87 \\
\hline & & $q G R 3.2$ & 3 & 3 & RM6832 & RM3513 & 4.00 & 9.36 & -5.52 & 6.08 \\
\hline & & qGR3.3 & 3 & 3 & RM3513 & RM8277 & 3.57 & 9.75 & -5.35 & 4.77 \\
\hline & & qGR6.1 & 3 & 6 & RM190 & Z602 & 6.11 & 23.99 & -8.51 & 3.73 \\
\hline & & qGR8.1 & 2 & 8 & RM3572 & RM6208 & 3.32 & 15.75 & -6.69 & -14.58 \\
\hline & & qGR8.2 & 2 & 8 & RM6208 & Y61 & 3.42 & 14.97 & -8.81 & -11.51 \\
\hline & & qGR10.1 & 2 & 10 & W13 & W20 & 3.33 & 9.25 & -9.95 & -1.11 \\
\hline & & & 3 & 10 & W13 & W20 & 3.33 & 8.95 & -3.93 & 2.89 \\
\hline & & qGR10.2 & 3 & 10 & W20 & RM6824 & 3.36 & 8.66 & -4.01 & 3.10 \\
\hline & $\mathrm{Gl}$ & $q G \mid 6.1$ & & 6 & RM190 & Z602 & 3.69 & 10.39 & -0.44 & 0.04 \\
\hline & & qG/10.1 & & 10 & W13 & W20 & 3.28 & 8.86 & -0.36 & 0.06 \\
\hline \multirow[t]{19}{*}{300 mM NaCl } & $G R$ & qGR6.1 & 13 & 6 & RM190 & Z602 & 3.14 & 7.07 & -5.40 & 4.54 \\
\hline & & qGR6.2 & 7 & 6 & Z604 & RM276 & 8.80 & 20.14 & -1.86 & -19.02 \\
\hline & & & 9 & 6 & Z604 & RM276 & 10.56 & 23.82 & -1.30 & -18.69 \\
\hline & & & 11 & 6 & Z604 & RM276 & 9.93 & 22.18 & -1.24 & -15.48 \\
\hline & & & 13 & 6 & Z604 & RM276 & 10.58 & 23.54 & -1.19 & -12.69 \\
\hline & & qGR8.1 & 5 & 8 & RM3572 & RM6208 & 4.00 & 18.80 & -7.76 & -8.00 \\
\hline & & qGR8.2 & 5 & 8 & RM6208 & Y61 & 3.84 & 14.48 & -7.17 & -6.24 \\
\hline & & qGR10.1 & 5 & 10 & W13 & W20 & 3.89 & 11.74 & -7.65 & -3.37 \\
\hline & & & 7 & 10 & W13 & W20 & 5.69 & 14.07 & -11.00 & 2.90 \\
\hline & & & 9 & 10 & W13 & W20 & 6.19 & 14.90 & -9.81 & 3.75 \\
\hline & & & 11 & 10 & W13 & W20 & 6.59 & 16.22 & -8.63 & 4.33 \\
\hline & & & 13 & 10 & W13 & W20 & 5.94 & 14.35 & -6.54 & 3.15 \\
\hline & & $q G R 10.2$ & 7 & 10 & W20 & RM6824 & 4.40 & 9.49 & -9.66 & 0.59 \\
\hline & & & 9 & 10 & W20 & RM6824 & 5.35 & 11.20 & -9.30 & 0.92 \\
\hline & & & 11 & 10 & W20 & RM6824 & 5.78 & 12.16 & -8.36 & 1.08 \\
\hline & & & 13 & 10 & W20 & RM6824 & 5.53 & 11.52 & -6.52 & 1.19 \\
\hline & & $q G \mid 6.2$ & & 6 & Z604 & $\mathrm{RM} 276$ & 11.20 & 24.39 & -0.05 & -0.72 \\
\hline & $\mathrm{Gl}$ & $q G / 10.1$ & & 10 & W13 & W20 & 7.50 & 17.41 & -0.41 & 0.14 \\
\hline & & $q G / 10.2$ & & 10 & W20 & RM6824 & 6.50 & 13.18 & -0.38 & 0.05 \\
\hline
\end{tabular}

GR germination rate, Gl germination index, Chr. chromosome, $L O D$ the likelihood of odds, $P V E$ phenotypic variation explained by each $Q T L, A D D$ additive effect is the effect of substituting a WJZ allele for a Nip allele, and its negative value indicates that WJZ contains the positive allele, DOM dominance effect

Under $300 \mathrm{mM} \mathrm{NaCl}$ conditions, six QTLs for GR and three for GI of seed germination were identified on chromosomes 6, 8, and 10, respectively (Table 2). All these QTLs showed a negative additive effect, indicating that the positive alleles originated from WJZ. Among the six QTLs for GR, qGR6.2 and qGR10.2 were continuously identified at $7,9,11$, and $13 \mathrm{~d}$ of seed imbibition, $q$ GR10.1 at 5, 7, 9, 11 and $13 \mathrm{~d}$ (Fig. 3), $q$ GR8.1 and $q G R 8.2$ only at $5 \mathrm{~d}$, and $q$ GR6.1 only at $13 \mathrm{~d}$. It suggested that $q$ GR6.2, qGR10.1 and qGR10.2 might be key QTLs of seed germination under salt stress (Table 2). A major-effective QTL qGR6.2 was flanked by Z604 and RM276, accounting for more than $20.0 \%$ of phenotypic variation. Three QTLs for GI, qGI6.2, qGI10.1 and qGI10.2, accounted for 24.39, 17.41 and $13.18 \%$ of phenotypic variation, respectively (Table 2). By comparison, qGR6.2 was co-localized with qGI6.2 between Z604 and RM276 on chromosome 6, and $q$ GR10.1 shared the same region with $q$ GI10.1 in the interval of W13 W20 on chromosome 10, qGR10.2 was co-localized with qGI10.2 between W20 and RM6824 on chromosome 10. Among those QTLs, the major QTL qGR6.2 or $q$ GI6.2 with a high LOD value $(>8)$ could specifically enhance GR or GI of seeds under salt conditions (Table 2). 


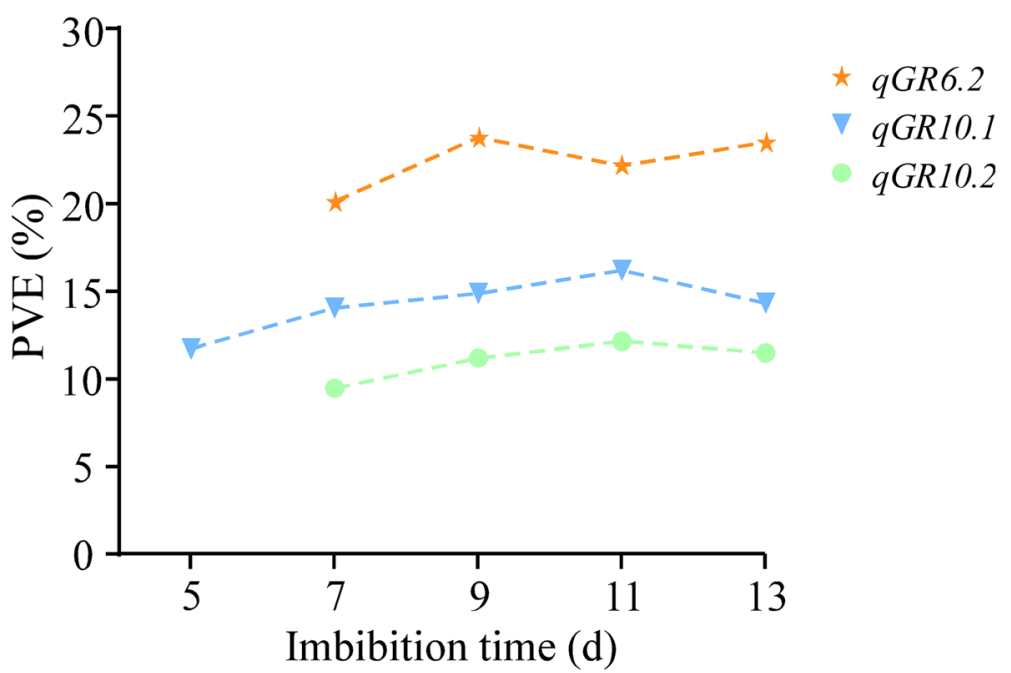

Fig. 3 QTLs associated with $G R$ in the $\mathrm{BC}_{1} \mathrm{~F}_{2}$ population under $300 \mathrm{mM} \mathrm{NaCl}$ conditions from 5 to $13 \mathrm{~d}$. PVE, phenotypic variation explained by QTL. Dashed lines show the trends of PVE for GR

\section{Validation and fine mapping of $q G R 6.2$}

To validate the major $q G R 6.2$ controlling seed germination under salt stress, we further structured a $\mathrm{BC}_{2} \mathrm{~F}_{2}$ population consisting of 70 individuals. There was a significant peak between markers Z604 and Z605 based on GR at $13 \mathrm{~d}$ under $300 \mathrm{mM} \mathrm{NaCl}$ conditions, and its phenotypic variation and LOD values were $19.50 \%$ and 9.31, respectively (Fig. 4). This result indicated that qGR6.2 could improve rice seed germination under salt stress.

A large $\mathrm{BC}_{2} \mathrm{~F}_{3}$ population consisting of 1205 individuals was developed to narrow the region of qGR6.2. Eighty-six recombinants were identified between Z604 and RM276 markers (Fig. 5). Eighteen recombinant events were between Z604 and Z616, 57 recombinant events were between Z617 and Z619, and eleven recombinant events were between Z605 and RM276 (Fig. 5). Based on the genotypes, these 86 recombinants were classified into four groups (A-D). For each group, we selected the homozygous individuals as the heterozygous region from the recombinants' progeny by selfing. The homozygous individuals were further divided into two kinds of genotypes, one genotype is from WJZ, and the other is from Nip. Seed germination under salt stress was assessed by the average GR values of the two different genotypes. In groups B or D, the average value of GR at $10 \mathrm{~d}$ for homozygous WJZ alleles was significantly higher than that for Nip alleles, while there was no difference in groups A or C. qGR6.2 was delimited between the Z617 and Z619 markers (Fig. 5). Similarly, the larger $\mathrm{BC}_{2} \mathrm{~F}_{4}$ population derived from heterozygous $\mathrm{BC}_{2} \mathrm{~F}_{3}$ plants in markers Z617 and Z619 was developed, containing 2318 individuals. Three types of recombination were obtained (E, F and G), consisting of 17 recombinants (Fig. 5), and the assay of each homozygous individual $\left(\mathrm{BC}_{2} \mathrm{~F}_{5}\right)$ from the recombinant group was conducted. Finally, the qGR6.2 locus was narrowed down to a 65.9-kb region between markers Z654 and Z619 (Fig. 5).

\section{Prediction and expression analysis of candidate genes in the $q G R 6.2$ locus}

According to the MSU Rice Genome Annotation Project Database (http://rice.plantbiology.msu.edu), eleven open reading frames (ORFs) were annotated within the 65.9$\mathrm{kb}$ region located in the qGR6.2 locus, including five functional proteins, one transposon protein and five expressed proteins without annotation (Table 3). Five genes with functional annotation showed that ORF1 (LOC_Os06g10650) encodes a tyrosine phosphatase family protein, ORF2 (LOC_Os06g10660) encodes a lysM domain-containing GPI-anchored protein 1 precursor, ORF3 (LOC_Os06g10670) encodes an aspartic proteinase nepenthesin-1 precursor, ORF5 (LOC_Os06g10690) encodes a PHD-finger domain-containing protein (PHD: plant homeodomain), and ORF11 (LOC_Os06g10750) encodes an integral membrane protein DUF6-containing protein (DUF6: Domain of unknown function).

Based on RNA-Seq data and array database deposited in GENEVESTIGATOR, the expression profiles of 10 ORFs in various developmental stages and seed imbibition were obtained, except for ORF10 encoding transposon protein (Fig. 6). The results showed that at the seed germination stage, there were higher transcript abundances for five genes, LOC_Os06g10650, LOC_Os06g10660, LOC_Os06g10690, ORF7 (LOC_Os06g10710) and ORF9 (LOC_Os06g10730), low transcript abundances for two genes, LOC_Os06g10670 and LOC_Os06g10750, and almost no expression for three genes, LOC_Os06g10680, LOC_Os06g10700 and 


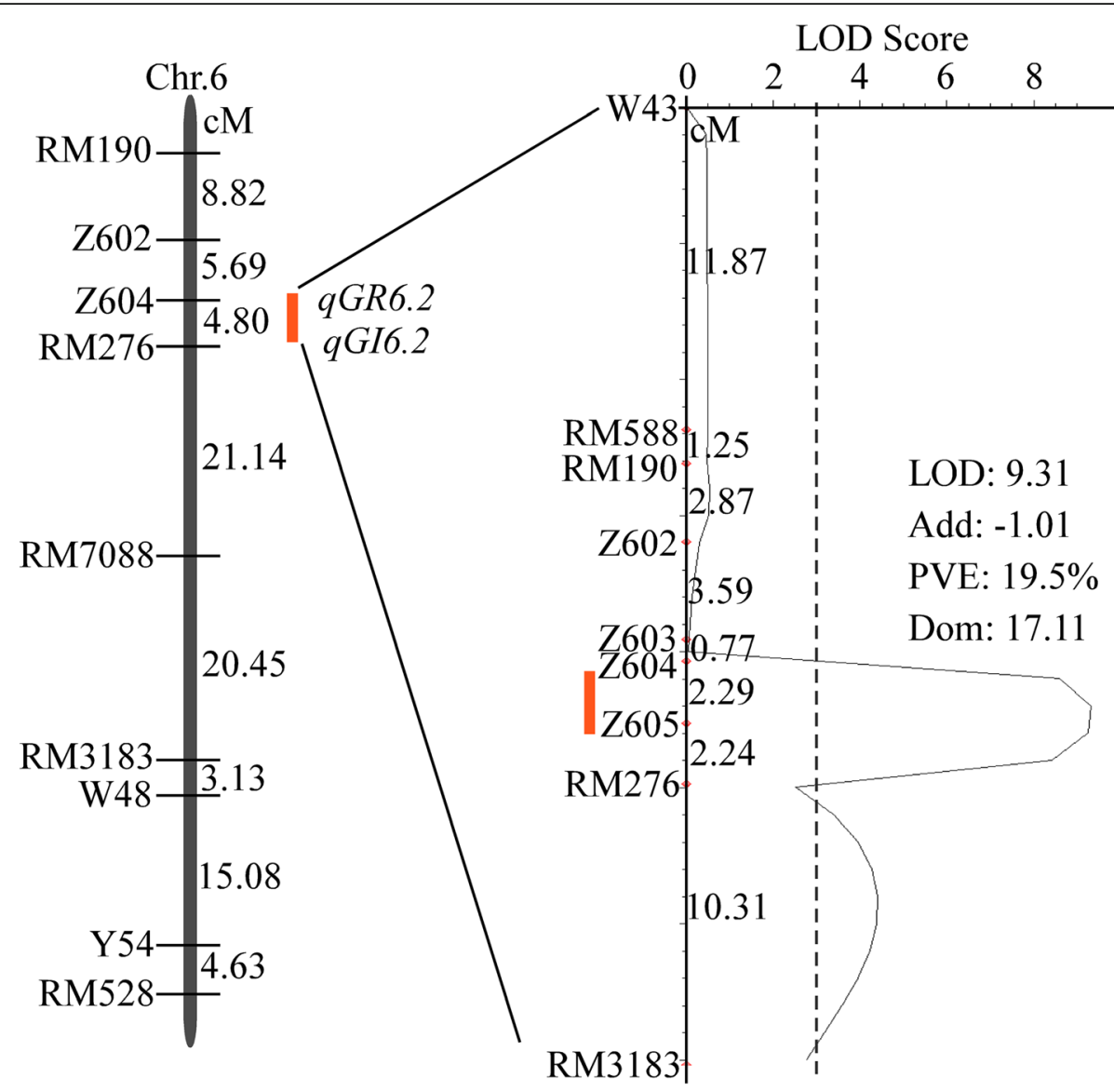

Fig. 4 QTL mapping and validation of $q G R 6.2$. On the left, the red line represents the region of $\mathrm{QTLS}$ among the $\mathrm{BC}_{1} \mathrm{~F}_{2}$ population, on the right, validation of $q G R 6.2$ among the $\mathrm{BC}_{2} \mathrm{~F}_{2}$ population under $300 \mathrm{mM} \mathrm{NaCl}$ conditions. The $\mathrm{LOD}$ curve indicates the strength of evidence for the presence of qGR6.2 within Z604 Z605 on chromosome 6. Dashed lines show LOD thresholds of 3.0. Marker names and genetic distances are shown on the right of the chromosome. Chr., chromosome; cM, centimorgan; LOD, the likelihood of odds; PVE, phenotypic variation explained by QTL; ADD, the additive effect of substituting a WJZ allele for a Nip allele, which its negative value indicates that WJZ contains the positive allele; DOM, dominance effect

LOC_Os06g10720 (Fig. 6a). During seed germination, the expression of LOC_Os06g10650 in the whole seeds or the isolated embryo was significantly upregulated, and LOC_Os06g10710 was down-regulated obviously (Fig. 6b).

With the quantitative real-time PCR (RT-qPCR) approach, we subsequently detected the expression of 5 ORFs (LOC_Os06g10650, LOC_Os06g10660, LOC_Os06g10690, LOC_Os06g10710 and LOC_OsO6g10730) in WJZ and Nip during seed germination under $300 \mathrm{mM} \mathrm{NaCl}$ conditions, which showed high transcript abundances at the seed germination stage based on GENEVESTIGATOR database. The expression of LOC_OsO6g10650 was up-regulated dramatically in both parents during seed germination under $300 \mathrm{mM} \mathrm{NaCl}$ conditions (Fig. 7a). The expression of $L O C_{-}$ Os06g10660 and LOC_Os06g10690 were smooth over time (Fig. 7b, c). The expression of LOC_Os06g 10710 and LOC_ Os06g10730 was slightly down-regulated during seed germination under salt stress (Fig. 7d, e). Compared to Nip, the significant higher expression of LOC_Os06g10650 in
WJZ seeds was observed after imbibition for $24 \mathrm{~h}$ and $36 \mathrm{~h}$. Taken together with gene function annotation and expression profiles, it indicates that ORF1 (LOC_Os06g10650), encoding a tyrosine phosphatase family protein might be the causal candidate gene for seed germination under salt stress in the qGR6.2 locus.

\section{Discussion}

Salinity seriously affects rice seed germination and seedling establishment, especially in the direct-seeding area, leading to rice reduction in yields $[10,11,20]$. In this study, the indica landrace WJZ from Yunnan Province in China showed a strong capability of seed germination and seedling establishment under high salinity. When exposed to $300 \mathrm{mM} \mathrm{NaCl}$, the seeds of WJZ could start to germinate after 2 days of imbibition and established normal seedlings after 5 days of imbibition. This finding suggests that WJZ is important germplasm with a strong capability of seed germination under high salinity, similar to other rice accessions N22-C-334-3 [25], Italica 


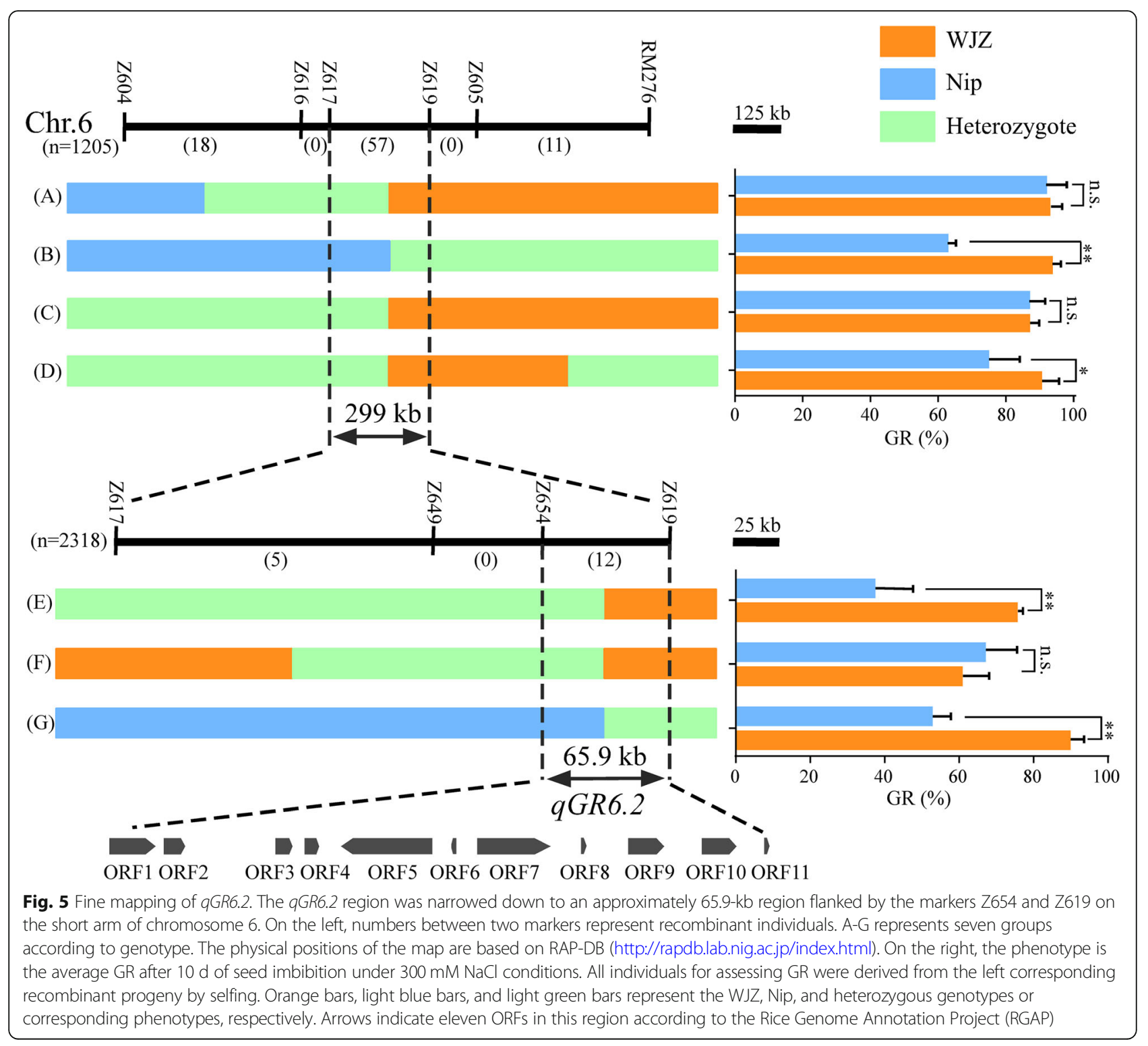

Livorno [23] and Jiucaiqing [24]. WJZ was considerably taller than Nip with $167.62 \mathrm{~cm}$ vs. $84.18 \mathrm{~cm}$ of plant height and fell down easily in field planting. Hence, it is of great importance to explore elite genes controlling seed germination under salt stress from WJZ, which will be beneficial for improving rice seed germination under salt stress in direct-sowing areas. As reported in previous studies, rice suffered from salinity stress during the whole growth stage, and salt tolerance at one developmental stage might not be correlated with salt tolerance at other stages $[20,26,27]$. WJZ has a very strong tolerance to salt stress at seed germination stage, however, it needs to be studied at other growth stages. Through pyramiding various salt-tolerance loci, or those loci expressing at germination, seedling, tillering or booting stages, it may be possible to develop new rice varieties with salt tolerance across all growth stages, and so improve production in rice direct-seeding areas or saline soils.

Evaluating the phenotype of salt tolerance comprehensively and accurately is the most crucial step for QTL mapping [26]. Previous studies showed that it's a good combination of final germination rate with germination index as germination parameters $[4,28]$. Both parameters showed correlation and provided reliable information on germination levels likewise temporal aspects of germination [28]. In this study, we evaluated seed germination using the parameters of GR and GI under $\mathrm{H}_{2} \mathrm{O}$ and $\mathrm{NaCl}$ conditions for the $\mathrm{BC}_{1} \mathrm{~F}_{2}$ population that was derived from a $\mathrm{BC}_{1} \mathrm{~F}_{1}$ individual containing approximately $37.76 \%$ genetic region of Nip (Fig. S1b). The continuous distribution and wide range of genetic variations in the $\mathrm{BC}_{1} \mathrm{~F}_{2}$ population were found during seed germination under $\mathrm{H}_{2} \mathrm{O}$ and 
Table 3 Predicted candidate genes of qGR6.2

\begin{tabular}{|c|c|c|}
\hline Number & Candidate genes & Putative protein function \\
\hline ORF1 & LOC_Os06g10650 & Tyrosine phosphatase family protein, putative, expressed \\
\hline ORF2 & LOC_Os06g10660 & $\begin{array}{l}\text { LysM domain-containing GPI-anchored protein } 1 \text { precursor, } \\
\text { putative, expressed }\end{array}$ \\
\hline ORF3 & LOC_Os06g10670 & $\begin{array}{l}\text { Aspartic proteinase nepenthesin-1 precursor, putative, } \\
\text { expressed }\end{array}$ \\
\hline ORF4 & LOC_Os06g10680 & Expressed protein \\
\hline ORF5 & LOC_Os06g10690 & PHD-finger domain containing protein, putative, expressed \\
\hline ORF6 & LOC_Os06g10700 & Expressed protein \\
\hline ORF7 & LOC_Os06g10710 & Expressed protein \\
\hline ORF8 & LOC_Os06g10720 & Expressed protein \\
\hline ORF9 & LOC_Os06g10730 & Expressed protein \\
\hline ORF10 & LOC_Os06g10740 & Transposon protein, putative, unclassified, expressed \\
\hline ORF11 & LOC_Os06g10750 & $\begin{array}{l}\text { Integral membrane protein DUF6-containing protein, } \\
\text { expressed }\end{array}$ \\
\hline
\end{tabular}

$\mathrm{NaCl}$ conditions, suggesting seed germination was regulated by various genes. Additionally, GR at $7 \mathrm{~d}$ under 300 $\mathrm{mM} \mathrm{NaCl}$ conditions showed symmetrical distribution, suggesting that there was great genetic variation at this time point and might be a crucial period for breaking through the seed coat to germinate under salt stress (Fig. 2e).

In this study, a total of 13 QTLs controlling seed germination were identified via QTL mapping under $\mathrm{H}_{2} \mathrm{O}$ and $300 \mathrm{mM} \mathrm{NaCl}$ conditions. All these QTLs could be used to improve rice seed germination and salt tolerance through gene pyramiding by MAS in the future. By comparison, qGR6.1, qGR8.1, qGR8.2, qGR10.1, qGR10.2 and qGI10.1 were consistently identified under both $\mathrm{H}_{2} \mathrm{O}$ and $300 \mathrm{mM} \mathrm{NaCl}$ conditions, suggesting they may simultaneously regulate seed germination and salt stress. qGR6.2, qGR10.1 and qGR10.2 were identified at different time points of seed germination and shared the same region with qGI6.2, qGI10.1 and qGI10.2, suggesting they are curial loci for seed germination under salt stress. By comparing chromosomal locations of reported QTLs, qGR3.3, qGR6.2, qGR10.1, qGI6.2 and qGI10.1 in the $\mathrm{BC}_{1} \mathrm{~F}_{2}$ population were located in the same or adjacent regions as previously reported QTLs. qGR3.3 was near the region of $q L T G-3-2$ for low-temperature germination ability reported by Fujino et al. in 2004 [29] and $q G R 3-1$ for germination rate reported by Cui et al. in 2002 [30]. qGR6.2 and qGI6.2 were close to the $q I R-6$ position for seed germination under salt stress reported by Wang et al. in 2011 [4], and one gene, OsRR22 was located within this region and involved salt tolerance at the seedling stage reported by Takagi et al. in 2015 [31]. The regions of $q$ GR10.1 and $q$ GI10.1 were similar to qSKC10 and qRKC10 identified for the shoot and root potassium content under salt stress at the seedling stage [26]. These results indicated that the co-localized QTLs at the different developmental stages were the weightily genomic regions for salt tolerance in rice.

Here, we focused on the major QTL qGR6.2, which was associated with both GR and GI under salt conditions. At last, $q G R 6.2$ was mapped in a region of $65.9 \mathrm{~kb}$ with eleven candidate genes. Among these eleven candidate genes, only ORF2 named LYP6 has been reported to play dual roles in peptidoglycan and chitin perception in rice innate immunity [32]. As reported previously, PTP family proteins have been reported to regulate signal transduction and control plant growth and development [33], and the PHD finger has been identified as one of the major families of histone reader domains, being involved in recognition of methylated H3K4 [34], so we speculated ORF1 (LOC_Os06g10650) and ORF5 (LOC_Os06g10690) might play similar functions in rice. Based on the GENEVESTIGATOR database and RT-qPCR, the expression of LOC_Os06g10650 was significantly upregulated, and there was a significant higher level in WJZ than Nip during seed germination under salt conditions, suggesting important roles of LOC_Os06g10650 in seed germination under salt stress. According to previous studies, AtPTP1, the first PTP family gene in the plant, was upregulated by high salt stress [35]. Another PTP family gene At5g23720 was reported to play import role in ABA signaling, of which mutant phs1-3 exhibited a strong ABAinduced inhibition of seed germination in Arabidopsis [36]. In rice genome, there were 132-protein phosphatase-coding genes in silico investigation [37], and they were categorized into PP2A, PP2C, PTP, DSP and LMWP classes according to domain analysis and phylogenetic analysis [37, 38]. Phylogenetic relationship results revealed that LOC_Os06g10650 


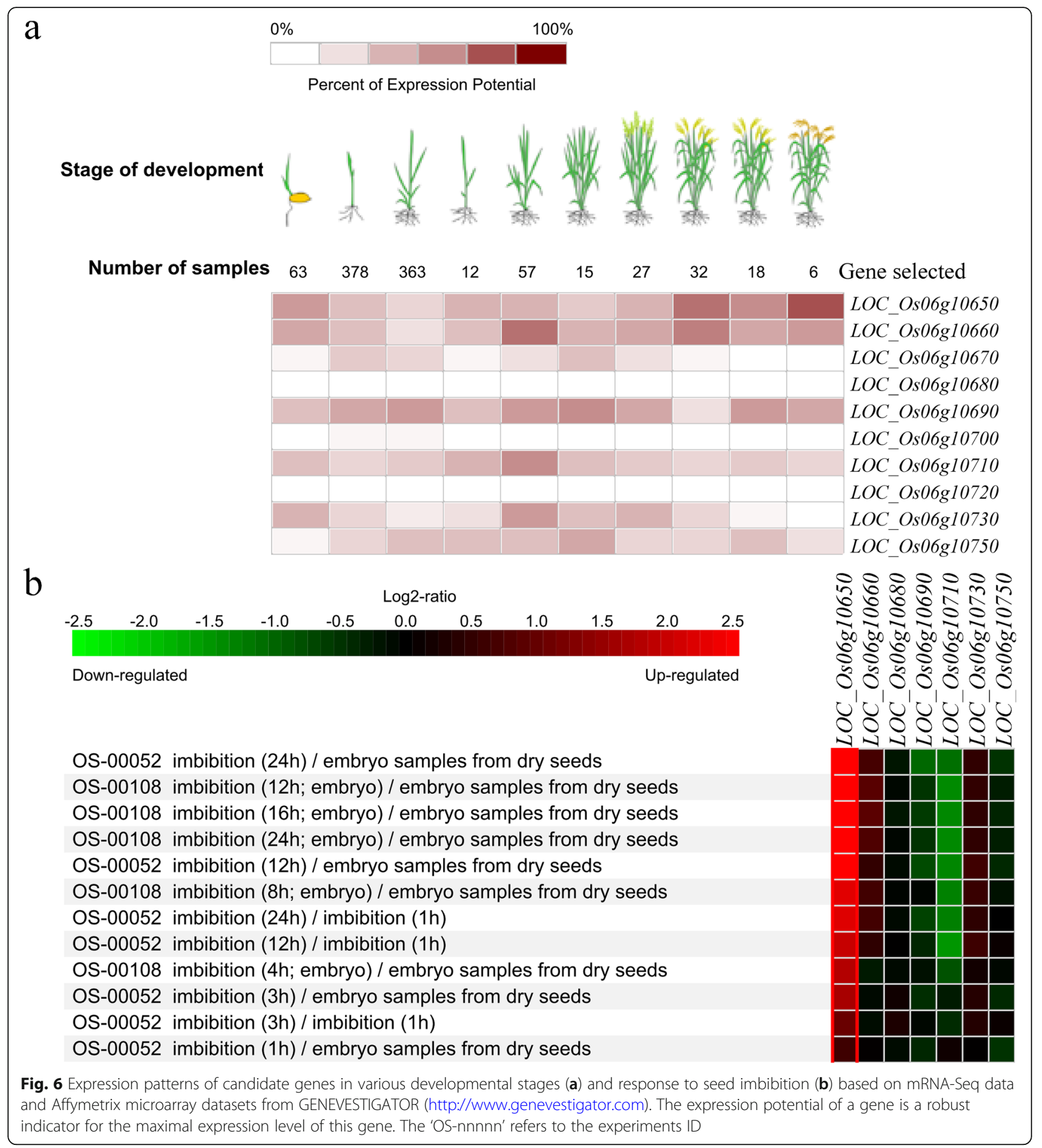

(OsPP68) belongs to PP2C class [37]. Expression profiles showed that there were 46 genes of phosphatase family to be differentially expressed under three abiotic stress conditions (salt, cold and drought) [37]. All these imply that LOC_OsO6g 10650 might be the causal candidate gene of qGR6.2. The function of it will be validated by genetic transformation using CRISPR/Cas9 or other method.

\section{Conclusions}

In this study, we identified 13 QTLs for seed germination traits under $\mathrm{H}_{2} \mathrm{O}$ and salt conditions, which provide information on the genetic basis of improving salt tolerance during seed germination by MAS. Of these loci, the major QTL qGR6.2, specifically for seed germination under salt stress, was fine mapped within a 


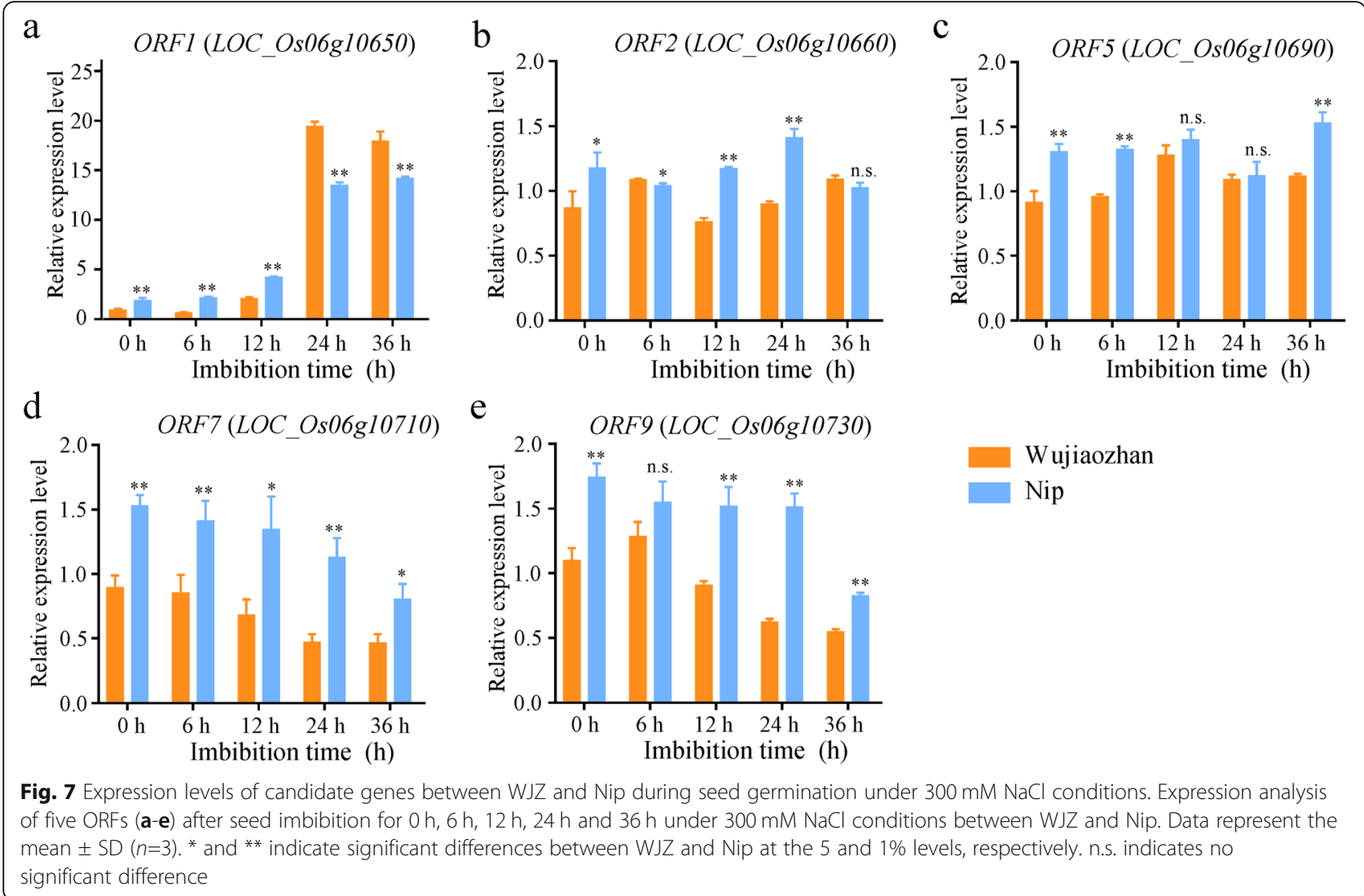

region of $65.9 \mathrm{~kb}$ with one more likely causal gene, LOC_Os06g10650. Sequence analysis and genetic transformation will be carried out in the future to validate the function of the candidate gene and elucidate the molecular mechanism underlying seed germination under salt stress. The major QTL $q$ GR6.2 could be highly useful for improving seed germination under salt stress by the MAS strategy.

\section{Materials and methods \\ Plant materials}

The indica landrace WJZ from Yunnan Province in China was crossed with japonica Nip to generate $F_{1}$. One $F_{3}$ individual plant with high germinability under salt stress was selected to obtained $\mathrm{BC}_{1} \mathrm{~F}_{1}$ seeds by backcrossing with Nip, and then a $\mathrm{BC}_{1} \mathrm{~F}_{1}$ individual plant with high germinability under salt stress was self-crossed to generate the $\mathrm{BC}_{1} \mathrm{~F}_{2}$ population. The $\mathrm{BC}_{1} \mathrm{~F}_{2}$ was backcrossed with Nip to produce the $\mathrm{BC}_{2} \mathrm{~F}_{2}$ population, and followed by self-crossed to generate $\mathrm{BC}_{2} \mathrm{~F}_{3}, \mathrm{BC}_{2} \mathrm{~F}_{4}$ and $\mathrm{BC}_{2} \mathrm{~F}_{5}$. The $\mathrm{BC}_{1} \mathrm{~F}_{2}$ and $\mathrm{BC}_{2} \mathrm{~F}_{2}$ populations were used for QTLs mapping, and $\mathrm{BC}_{2} \mathrm{~F}_{3}, \mathrm{BC}_{2} \mathrm{~F}_{4}$ and $\mathrm{BC}_{2} \mathrm{~F}_{5}$ were used for fine mapping of $q$ GR6.2. All plants were grown in a paddy field at the Jiangpu Experimental Station of Nanjing Agricultural University (Jiangsu Province, China) with 17 $\mathrm{cm}$ between plants within a row and $33 \mathrm{~cm}$ between rows. The seeds of each line or individual were harvested at maturity and dried at $42^{\circ} \mathrm{C}$ for $7 \mathrm{~d}$ to break seed dormancy and then stored at $-20^{\circ} \mathrm{C}$.

\section{Evaluation of seed germination under $\mathrm{H}_{2} \mathrm{O}$ and $\mathrm{NaCl}$ conditions}

A total of 30 healthy grains from each line were surfacesterilized with $0.5 \%$ sodium hypochlorite solution for 15 min and then rinsed three times with sterile distilled water. Seeds were imbibed in a Petri dish (diameter 9 $\mathrm{cm}$ ) with $40 \mathrm{~mL}$ quartz (diameter $1 \sim 2 \mathrm{~mm}$ ) and $20 \mathrm{~mL}$ solution for $10 \mathrm{~d}$ under $\mathrm{H}_{2} \mathrm{O}$ conditions and $14 \mathrm{~d}$ under $\mathrm{NaCl}$ conditions, respectively. The different $\mathrm{NaCl}$ solutions $(0 \mathrm{mM}, 150 \mathrm{mM}, 200 \mathrm{mM}, 250 \mathrm{mM}, 300 \mathrm{mM}$, and $350 \mathrm{mM}$ ) were applied for two parents to determine the fitting salt concentration of treatment. $0 \mathrm{mM}$ and 300 $\mathrm{mM} \mathrm{NaCl}$ solutions were used for the $\mathrm{BC}_{1} \mathrm{~F}_{2}$ population to detect QTLs responsible for seed germination under $\mathrm{H}_{2} \mathrm{O}$ and $\mathrm{NaCl}$ conditions. The evaluation of seed germination under $300 \mathrm{mM} \mathrm{NaCl}$ was conducted for fine mapping of target QTL among the $\mathrm{BC}_{2} \mathrm{~F}_{2}, \mathrm{BC}_{2} \mathrm{~F}_{3}, \mathrm{BC}_{2} \mathrm{~F}_{4}$ and $\mathrm{BC}_{2} \mathrm{~F}_{5}$ populations. All seeds were grown at $25 \pm 1{ }^{\circ} \mathrm{C}$ in a growth chamber under $12 \mathrm{~h}$ light $/ 12 \mathrm{~h}$ day conditions. Seed germination was defined as the emergence of 
the radicle $(2 \mathrm{~mm})$ through the surrounding tissue, and the seedling establishment was considered when the root length reached the seed length and the shoot length reached half of the seed length [21]. Germination ability was observed every day to calculate the germination rate (GR) and seedling percentage (SP). The germination index (GI) was calculated as GI $=\sum(G t / t)$, where $G t$ is the number of germinated seeds on day $t$ [4]. Three replications of each line were performed.

\section{DNA extraction and PCR analysis}

Total genomic DNA was extracted from the young leaves of each plant using the cetyltrimethylammonium bromide (CTAB) method. PCR was performed as described by Chen et al. [39]. The PCR products were separated by electrophoresis through $8 \%$ nondenaturing polyacrylamide gels and visualized by silver staining [40].

\section{QTL mapping}

According to the International Rice Microsatellite Initiative (IRMI, http://www.gramene.org) [41], a total of 157 SSR or InDel markers were polymorphic between WJZ and Nip and scattered on 12 chromosomes (Table S1). The $\mathrm{BC}_{1} \mathrm{~F}_{2}$ population with 181 individuals was used to construct a genetic map by Mapmaker/Exp 3.0 [42]. GR at 2 and $3 \mathrm{~d}$ under $\mathrm{H}_{2} \mathrm{O}$ conditions and GI, GR at 5, 7, 9, 11 and $13 \mathrm{~d}$ and GI under $300 \mathrm{mM} \mathrm{NaCl}$ conditions were used for QTL mapping. QTL analysis was carried out by Inclusive Composite Interval Mapping (ICIM) [43] with a threshold of LOD > 3 operating 1000 permutations. The phenotypic variation and additive and dominance effects of each QTL were estimated.

\section{Validation and fine mapping of $q G R 6.2$}

Six polymorphic InDel markers were developed and used for validation and fine mapping of $q G R 6.2$ (Table S2). A linkage map of 70 individuals from the $\mathrm{BC}_{2} \mathrm{~F}_{2}$ population was analyzed with 9 SSR markers (Fig. 4) on chromosome 6 to ensure the presence of the major QTL qGR6.2. A total of $1205 \mathrm{BC}_{2} \mathrm{~F}_{3}$ individuals were used to screen recombinants between the Z604 and RM276 markers, and $2318 \mathrm{BC}_{2} \mathrm{~F}_{4}$ individuals were used to screen recombinants between the Z617 and Z619 markers. In total, seven types of recombinants were identified. Twenty progenies of each recombinant were planted and screened for homozygous plants from each group. These homozygous plants $\left(\mathrm{BC}_{2} \mathrm{~F}_{4}, \mathrm{BC}_{2} \mathrm{~F}_{5}\right)$ were tested for seed germination under $300 \mathrm{mM} \mathrm{NaCl}$ conditions. The average GR value of seed in each group after $10 \mathrm{~d}$ of imbibition was used for fine mapping.

\section{Prediction and expression analysis of candidate genes} Open reading frames (ORFs) in the region of markers Z654 and Z619 were predicted by the Rice Annotation Project
Database (http://rice.plantbiology.msu.edu/). GENEVE STIGATOR (https://genevestigator.com/gv/) was employed to analyze the expression patterns of eleven candidate genes based on 2836 Affymetrix microarray datasets and 565 RNA-Seq data in seed imbibition with a significance level of $P<0.05$.

Seeds of two parents were sampled after $0 \mathrm{~h}, 6 \mathrm{~h}, 12 \mathrm{~h}$, $24 \mathrm{~h}$ and $36 \mathrm{~h}$ imbibition at $300 \mathrm{mM} \mathrm{NaCl}$, frozen quickly in liquid nitrogen and stored at $-80^{\circ} \mathrm{C}$ for RNA extraction. Total RNA was isolated from approximately 80 100 mg powder with a total RNA Kit (BioTeke, http://www.bioteke.com). The first-strand cDNA was synthesized with random oligonucleotides using the HiScript II Reverse kit (Vazyme Biotech, http://www. vazyme.com/) according to the manufacturer's protocol. To measure the mRNA levels of genes, RT-qPCR was conducted using a CFX96 Real-time System (Bio-Rad, USA) with SYBR Green Mix (Vazyme). The rice housekeeping gene OsActin (LOC_OsO3g50885) was used as an internal control [44]. The PCR conditions were as follows: $95^{\circ} \mathrm{C}$ for $5 \mathrm{~min}$ followed by 40 cycles of $95^{\circ} \mathrm{C}$ for $15 \mathrm{~s}$ and $60^{\circ} \mathrm{C}$ for $30 \mathrm{~s}$. A final melt curve stage of $65-95^{\circ} \mathrm{C}$ was performed to confirm the specificity of the primers. Relative quantification of transcript levels was obtained based on the $2^{-\Delta \Delta C T}$ method [45]. The amount of the transcripts in the WJZ after imbibing for $0 \mathrm{~h}$ was set at 1.0. All of the primers used for RT-qPCR (Table S3) were designed according to http://quantprime. mpimp-golm.mpg.de/. Three biological replicates were conducted.

\section{Data analysis}

The experimental data were analyzed using Statistical Analysis System (SAS) software (Cary, NC, USA) and compared with Student's $t$-test at the 5 and $1 \%$ levels of probability.

\section{Supplementary Information}

The online version contains supplementary material available at https://doi. org/10.1186/s12870-020-02820-7

\footnotetext{
Additional file 1: Figure S1. Overview of the mapping populations and the genetic basis of $\mathrm{BC}_{1} \mathrm{~F}_{1}$. (a) A flow chart that describes the construction of the mapping population in this study. (b) The genetic basis of a $\mathrm{BC}_{1} \mathrm{~F}_{1}$ individual plant was derived from the backcrossing of one $F_{3}$ single plant with Nip. The light blue, light green, and gray regions represent segments derived from Nip, heterozygous, and the centromere, on 12 chromosomes (listed as 1 to 12 ), respectively. The mapped markers are positioned by chromosome assignment from the high-density restriction fragment length polymorphism linkage map and described in Table S1.
}

Additional file 2: Table S1. Summary of 157 pairs of polymorphic SSR or InDel markers between WJZ and Nip.

Additional file 3: Table S2. Primers of PCR-based markers used for validation and fine mapping $9 G R 6.2$.

Additional file 4: Table S3. Primers for expression pattern analysis of candidate genes by real-time PCR (RT-qPCR). 


\section{Abbreviations}

WJZ: Wujiaozhan; Nip: Nipponbare; GR: Germination rate; SP: Seedling percentage; Gl: Germination index; QTLs: Quantitative trait loci; MAS: Markerassisted selection; GWAS: Genome-wide association studies; PVE: Phenotypic variation explained by QTL; SSR: Simple sequence repeats; InDel: Insertion/ Deletion; ORF: Open reading frame; PTP: Protein tyrosine phosphatase; CTAB: Cetyltrimethylammonium bromide; RT-qPCR: Quantitative real-time PCR

\section{Acknowledgements}

The authors would thank Dr. Luyuan Dai at Yunnan Academy of Agricultural Sciences for providing the WJZ seeds.

\section{Authors' contributions}

J. C., H. Z. and P. Z.1 conceived the project and designed the research. P. Z.1 performed most of the experiments and analyzed the data; P. Z.2 performed seed germination test for fine mapping; P. Z.1 and L. Q. constructed the genetic map; X. Q., Y. M., Z. L. and S. D. participated in developing plant populations. H. A. provided technical assistance with English writing. P. Z.1 and J. C. wrote the manuscript. H. Z. and J. C. supervised and complemented the writing. P. Z.1 and P. Z.2 are corresponding to Peng Zeng and Peiwen Zhu respectively. All authors read and approved the final manuscript.

\section{Funding}

This work was supported by the National Key Research and Development Plan (Grant No. 2018YFD0100901) and the National Natural Science Foundation of China (Grant No. 31771757, 31771889, 31601387).

\section{Availability of data and materials}

The WJZ seeds are provided by Dr. Luyuan Dai at Yunnan Academy of Agricultural Sciences. The datasets used and/or analysed during the current study are available from the corresponding author on reasonable request. The raw data regarding to linked genotype and phenotype for QTL mapping are available via figshare (https://doi.org/10.6084/m9.figshare.13413674.v1).

\section{Ethics approval and consent to participate}

Not applicable.

\section{Consent for publication}

Not applicable.

\section{Competing interests}

The authors declare no conflicts of interest.

\section{Author details}

'State Key Laboratory of Crop Genetics and Germplasm Enhancement, Jiangsu Collaborative Innovation Center for Modern Crop Production, Cyrus Tang Innovation Center for Crop Seed Industry, Nanjing Agricultural University, Nanjing, China. ${ }^{2}$ Department of Biological and Environment Sciences, University of Gothenburg, Gothenburg, Sweden.

Received: 2 July 2020 Accepted: 25 December 2020

Published online: 09 January 2021

\section{References}

1. Zhu JK. Plant salt tolerance. Trends Plant Sci. 2001;6(2):66-71.

2. Munns R, Tester M. Mechanisms of salinity tolerance. Annu Rev Plant Biol. 2008;59:651-81.

3. Takehisa H, Shimodate T, Fukuta Y, Ueda T, Yano M, Yamaya T, Kameya T, Sato T. Identification of quantitative trait loci for plant growth of rice in paddy field flooded with salt water. Field Crop Res. 2004;89:85-95.

4. Wang ZF, Wang JF, Bao YM, Wu YY, Zhang HS. Quantitative trait loci controlling rice seed germination under salt stress. Euphytica. 2011;178(3): 297-307.

5. Asch F, Wopereis MCS. Responses of field-grown irrigated rice cultivars to varying levels of floodwater salinity in a semi-arid environment. F Crop Res. 2001;70(2):127-37.

6. Munns R, Gilliham M. Salinity tolerance of crops - what is the cost? New Phytol. 2015;208(3):668-73.

7. Reddy INBL, Kim BK, Yoon IS, Kim KH, Kwon TR. Salt tolerance in rice: focus on mechanisms and approaches. Ric Sci. 2017;24(003):123-44.
8. Zhu JK. Genetic analysis of plant salt tolerance using arabidopsis. Plant Physiol. 2000;124(3):941-8.

9. Johnson DW, Smith SE, Dobrenz AK. Genetic and phenotypic relationships in response to $\mathrm{NaCl}$ at different developmental stages in alfalfa. Theor Appl Genet. 1992;83:833-8.

10. Wang ZF, Cheng JP, Chen ZW, Huang J, Bao YM, Wang JF, Zhang HS Identification of QTLs with main, epistatic and QTL $\times$ environment interaction effects for salt tolerance in rice seedlings under different salinity conditions. Theor Appl Genet. 2012;125:807-15.

11. Ganie SA, Molla KA, Henry RJ, Bhat KV, Mondal MT. Advances in understanding salt tolerance in rice. Theor Appl Genet. 2019;132:851-70.

12. Lin $H X$, Zhu MZ, Yano M, Gao JP, Liang ZW, Su WA, Hu XH, Ren ZH, Chao DY. QTLs for $\mathrm{Na}^{+}$and $\mathrm{K}^{+}$uptake of the shoots and roots controlling rice salt tolerance. Theor Appl Genet. 2004;108:253-60.

13. Ren ZH, Gao JP, Li LG, Cai XL, Huang W, Chao DY, Zhu MZ, Wang ZY, Luan $S$, Lin HX. A rice quantitative trait locus for salt tolerance encodes a sodium transporter. Nat Genet. 2005:37:1141-6.

14. Thomson MJ, de Ocampo M, Egdane J, Rahman MA, Sajise AG, Adorada DL, Tumimbang-Raiz E, Bluwald E, Seraj ZI, Singh RK, Gregorio GB, Ismail AM. Characterizing the Saltol quantitative trait locus for salinity tolerance in rice. Rice. 2010;3:148-60.

15. Huyen LTN, CuC LM, Ismail AM, Ham LH. Introgression the salinity tolerance QTLs Saltol into AS996, the elite rice variety of Vietnam. Am J Plant Sci. 2012;03:981-7.

16. Sahi $C$, Singh A, Kumar K, Blumwald E, Grover A. Salt stress response in rice: genetics, molecular biology, and comparative genomics. Funct Integr Genomics. 2006;6(4):263-84.

17. Bewley JD. Seed germination and dormancy. Plant Cell. 1997;9:1055-66.

18. Gomes-Filho E, Lima CRFM, Costa JH, Da Silva ACM, Da Guia Silva Lima M, De Lacerda CF, Prisco JT. Cowpea ribonuclease: properties and effect of $\mathrm{NaCl}$-salinity on its activation during seed germination and seedling establishment. Plant Cell Rep. 2008:27(1):147-57.

19. Shereen A, Ansari R, Raza S, Mumtaz S, Khan MA, Ali Khan MA. Salinity induced metabolic changes in rice (Oryza sativa L.) seeds during germination. Pakistan J Bot. 2011;43(3):1659-61.

20. Shi YY, Gao LL, Wu ZC, Zhang XJ, Wang MM, Zhang CS, Zhang F, Zhou YL, Li ZK. Genome-wide association study of salt tolerance at the seed germination stage in rice. BMC Plant Biol. 2017:17:92

21. Cheng JP, He YQ, Yang B, Lai YY, Wang ZF, Zhang HS. Association mapping of seed germination and seedling growth at three conditions in indica rice (Oryza sativa L.). Euphytica. 2015;206(1):103-15.

22. Yu J, Zhao WG, Tong W, He Q, Yoon MY, Li FP, Choi B, Heo EB, Kim KW, Park YJ. A genome-wide association study reveals candidate genes related to salt tolerance in rice (Oryza sativa) at the germination stage. Int J Mol Sci. 2018:19(10):3145.

23. Fujino K, Sekiguchi H, Matsuda Y, Sugimoto K, Ono K, Yano M. Molecular identification of a major quantitative trait locus, aLTG3-1, controlling lowtemperature germinability in rice. Proc Natl Acad Sci U S A. 2008;105(34): 12623-8.

24. He YQ, Yang B, He Y, Zhan CF, Cheng YH, Zhang JH, Zhang HS, Cheng JP, Wang ZF. A quantitative trait locus, aSE3, promotes seed germination and seedling establishment under salinity stress in rice. Plant J. 2019;97:1089-104.

25. Ashokkumar K, Raveendran M, Senthil N, Vijayalaxmi D, Sowmya M, Sharma RP, Sobin S. Isolation and characterization of altered root growth behavior and salinity tolerant mutants in rice. Afr J Biotechnol. 2013;12:5852-9.

26. Wang ZF, Chen ZW, Cheng JP, Lai YY, Wang JF, Bao YM, Huang J, Zhang HS. QTL analysis of $\mathrm{Na}^{+}$and $\mathrm{K}^{+}$concentrations in roots and shoots under different levels of $\mathrm{NaCl}$ stress in rice (Oryza sativa L.). PLoS One. 2012;7(12):e51202.

27. Chai L, Zhang J, Pan XB, Zhang F, Zheng TQ, Zhao XQ, Wang WS, Jauhar A, Xu JL, Li ZK. Advanced backcross QTL analysis for the whole plant growth duration salt tolerance in rice (Oryza sativa L.). J Integr Agric. 2014;13(8): 1609-20.

28. Al-Ansari F, Ksiksi T. A quantitative assessment of germination parameters: the case of Crotalaria Persica and Tephrosia Apollinea. Open Ecol J. 2016;9:13-21.

29. Fujino $K$, Sekiguchi $H$, Sato $T$, Kiuchi $H$, Nonoue $Y$, Takeuchi $Y$, Ando T, Lin SY, Yano M. Mapping of quantitative trait loci controlling low-temperature germinability in rice (Oryza sativa L.). Theor Appl Genet. 2004;108:794-9.

30. Cui KH, Peng SB, Xing YZ, Xu CG, Yu SB, Zhang Q. Molecular dissection of seedling-vigor and associated physiological traits in rice. Theor Appl Genet. 2002;105:745-53. 
31. Takagi H, Tamiru M, Abe A, Yoshida K, Uemura A, Yaegashi H, Obara T, Oikawa K, Utsushi H, Kanzaki E, Mitsuoka C, Natsume S, Kosugi S, Kanzaki H, Matsumura H, Urasaki N, Kamoun S, Terauchi R. MutMap accelerates breeding of a salt-tolerant rice cultivar. Nat Biotechnol. 2015;33:445-9.

32. Liu B, Li JF, Ao Y, Qu JW, Li ZQ, Su JB, Zhang Y, Liu J, Feng DR, Qi KB, He YM, Wang JF, Wang HB. Lysin motif-containing proteins LYP4 and LYP6 play dual roles in peptidoglycan and chitin perception in rice innate immunity. Plant Cell. 2012;24(8):3406-19.

33. Stoker AW. Protein tyrosine phosphatases and signalling. J Endocrinol. 2005; 185:19-33.

34. Morrison EA, Musselman CA. The role of PHD fingers in chromatin signaling: mechanisms and functional consequences of the recognition of histone and non-histone targets. In: Binda O, Fernandez-Zapico ME, editors. Chromatin signaling and diseases. London: Academic; 2016. p. 127-47.

35. Xu Q, Fu HH, Gupta R, Luan S. Molecular characterization of a tyrosinespecific protein phosphatase encoded by a stress-responsive gene in Arabidopsis. Plant Cell. 1998;10:849-57.

36. Quettier AL, Bertrand C, Habricot Y, Miginiac E, Agnes C, Jeannette E, Maldiney R. The phs 1-3 mutation in a putative dual-specificity protein tyrosine phosphatase gene provokes hypersensitive responses to abscisic acid in Arabidopsis thaliana. Plant J. 2006;47:711-9.

37. Singh A, Giri J, Kapoor S, Tyagi AK, Pandey GK. Protein phosphatase complement in rice: genome-wide identification and transcriptional analysis under abiotic stress conditions and reproductive development. BMC Genomics. 2010;11:435

38. Yang M, Song SH, Liu GM, Chen KF, Tian XJ, Joe Zhao ZJ, Hu SN, Yu J. A comprehensive analysis of protein phosphatases in rice and Arabidopsis. Plant Syst Evol. 2010;289:111-26.

39. Chen X, Temnykh S, Xu Y, Cho YG, McCouch SR. Development of a microsatellite framework map providing genome-wide coverage in rice (Oryza sativa L.). Theor Appl Genet. 1997;95(4):553-67.

40. Sanguinetti CJ, Neto ED, Simpson AJG. Rapid silver staining and recovery of $\mathrm{PCR}$ products separated on polyacrylamide gels. Biotechniques. 1994;17(5):914-21.

41. McCouch SR, Teytelman L, Xu YB, Lobos KB, Clare K, Walton M, Fu BY, Maghirang R, Li ZK, Xing YZ, Zhang QF, Kono I, Yano M, Fjellstrom R, DeClerck G, Schneider D, Cartinhour S, Ware D, Stein L. Development and mapping of 2240 new SSR markers for rice (Oryza sativa L.). DNA Res. 2002; 9(6):199-207.

42. Lander ES, Green P, Abrahamson J, Barlow A, Daly MJ, Lincoln SE, Newburg L. MAPMAKER: an interactive computer package for constructing primary genetic linkage maps of experimental and natural populations. Genomics. 1987;1:174-81.

43. Li HH, Ribaut JM, Li ZL, Wang JK. Inclusive composite interval mapping (ICIM) for digenic epistasis of quantitative traits in biparental populations. Theor Appl Genet. 2008;116(2):243-60

44. Zhou J, Jiao FC, Wu ZC, Li YY, Wang XM, He XW, Zhong WQ, Wu P. OsPHR2 is involved in phosphate-starvation signaling and excessive phosphate accumulation in shoots of plants. Plant Physiol. 2008;146:1673-86.

45. Livak KJ, Schmittgen TD. Analysis of relative gene expression data using realtime quantitative PCR and the $2^{-\Delta \Delta C T}$ method. Methods. 2001;25(4):402-8.

\section{Publisher's Note}

Springer Nature remains neutral with regard to jurisdictional claims in published maps and institutional affiliations.

Ready to submit your research? Choose BMC and benefit from:

- fast, convenient online submission

- thorough peer review by experienced researchers in your field

- rapid publication on acceptance

- support for research data, including large and complex data types

- gold Open Access which fosters wider collaboration and increased citations

- maximum visibility for your research: over $100 \mathrm{M}$ website views per year

At BMC, research is always in progress.

Learn more biomedcentral.com/submissions 